\title{
Structure, atomistic simulations, and phase transition of stoichio- metric yeelimite
}

\author{
Ana Cuesta, ${ }^{\dagger}$ Angeles G. De la Torre, ${ }^{\dagger}$ Enrique R. Losilla, ${ }^{\dagger}$ Vanessa K. Peterson, ${ }^{\ddagger}$, Pawel Rejmak, ${ }^{\star}$ An- \\ drés Ayuela, ${ }^{\# \S}$ Carlos Frontera, ${ }^{\&}$ and Miguel A.G. Aranda, ${ }^{*, \dagger, \pm}$ \\ † Departamento de Química Inorgánica, Universidad de Málaga, Campus Teatinos s/n, Málaga-29071, Spain. \\ ‡ Australian Nuclear Science and Technology Organisation, Lucas Heights, NSW 2234, Australia. \\ \# Donostia International Physics Center (DIPC), p. Manuel de Lardizabal 4, Donostia-San Sebastián, Spain. \\ $\S$ Centro de Física de Materiales CFM-MPC CSIC-UPV/EHU, Departamento de Física de Materiales, Facultad de Químicas, \\ Universidad del Pais Vasco UPV-EHU, 20018 Donostia-San Sebastián, Spain \\ \& ICMAB-CSIC, Campus universitari de Bellaterra, E-08193, Bellaterra, Barcelona, Spain. \\ ${ }^{ \pm}$CELLS-Alba synchrotron, Carretera BP 1413, Km. 3.3, E-08290 Cerdanyola, Barcelona, Spain.
}

KEYWORDS. Sodalite, Rietveld refinement, DFT calculations, phase transition, sulfoaluminate cements

Supporting Information Placeholder

\begin{abstract}
Yeelimite, $\mathrm{Ca}_{4}\left[\mathrm{Al}_{6} \mathrm{O}_{12}\right] \mathrm{SO}_{4}$, is outstanding as an aluminate sodalite, being the framework of these type of materials flexible and dependent on ion sizes and anion ordering/disordering. On the other hand, yeelimite is also important from an applied perspective as it is the most important phase in calcium sulfoaluminate cements. However, its crystal structure is not well studied. Here, we characterize the room temperature crystal structure of stoichiometric yeelimite through joint Rietveld refinement using neutron and X-ray powder diffraction data coupled with chemical soft-constraints. Our structural study shows that yeelimite has a lower symmetry than that of the previously-reported tetragonal system, which we establish to likely be the acentric orthorhombic space group $P c c 2$, with a $\sqrt{2} \mathrm{a} \times \sqrt{2} \mathrm{a} \times \mathrm{a}$ superstructure based on the cubic sodalite structure. Final unit cell values were a=13.0356(7) $\AA, b=13.0350(7) \AA$, and $c=9.1677(2) \AA$. We determine several structures using density functional theory calculations, with the lowest energy structure being Pcc2 in agreement with our experimental result. Yeelimite undergoes a reversible phase transition to a higher-symmetry phase which has been characterized to occur at $470^{\circ} \mathrm{C}$ by thermodiffractometry. The higher-symmetry phase is likely cubic or pseudo-cubic possessing an incommensurate superstructure, as suggested by our theoretical calculations which show a phase transition from an orthorhombic to a tetragonal structure. Our theoretical study also predicts a pressure-induced phase transition to a cubic structure of space group $I \underline{4} 3 \mathrm{~m}$. Finally, we show that our reported crystal structure of yeelimite enables better mineralogical phase analysis of commercial calcium sulfoaluminate cements, as shown by $\mathrm{R}_{\mathrm{F}}$ values for this phase, $6.9 \%$ and $4.8 \%$ for the previously published orthorhombic structure and for the one reported in this study, respectively.
\end{abstract}

\section{INTRODUCTION}

Sodalites of the general composition $\mathrm{M}_{4}\left[\mathrm{~T}_{6} \mathrm{O}_{12}\right] \mathrm{X}$ have been known for many years as both naturally-occurring minerals and as synthetic compounds. ${ }^{1}$ This general formula refers to a structure that is (ideally) a body-centered cubic unit cell with a lattice parameter of $9 \AA$ and where $\mathrm{M}$ is a relatively lowcharged cation such as $\mathrm{Na}$, $\mathrm{Ca}$, or $\mathrm{Sr}$; $\mathrm{T}$ occupies tetrahedral sites(s) and is typically $\mathrm{Si}$ or $\mathrm{Al}$; and $\mathrm{X}$ is an anion which is either spherical (in the case of $\mathrm{Cl}$ ) or tetrahedral (in the case of $\mathrm{SO}_{4}, \mathrm{WO}_{4}$, and $\mathrm{CrO}_{4}$ ). The archetype of this family of compounds is the mineral sodalite, with chemical formula $\mathrm{Na}_{4}\left[\mathrm{Al}_{3} \mathrm{Si}_{3} \mathrm{O}_{12}\right] \mathrm{Cl}$ and crystallizing in the $P \underline{4} 3 n$ space group with lattice parameter $8.88 \AA$ and $Z=2$. Partial replacement of chloride by sulphate and the concomitant (partial) replacement of sodium by calcium yields the mineral hauynite. ${ }^{1}$ This cagecontaining framework allows a large degree of cation and anion substitution/variability that we do not discuss here but refer the interested reader instead to a recent review ${ }^{2 a}$ dealing with the stoichiometries and structures of this rich family of minerals and materials. A second review ${ }^{2 b}$ deals with the symmetry relationships of compounds with sodalite framework, with more than 25 space groups being reported.

Depending on the $\mathrm{Si} / \mathrm{Al}$ ratio and the type of cage ions, different sodalite compounds can be produced with a range of interesting properties and features such as negative thermal expansion, ${ }^{3}$ ferroelectric behavior, ${ }^{4} \mathrm{~F}$ centers, ${ }^{5}$ s-electron antiferromagnetism, ${ }^{6}$ catalytic activity, ${ }^{7}$ tunable electronic properties $^{8}$ and optical emission. ${ }^{9}$ Sodalites with $\mathrm{X}=\mathrm{S}_{\mathrm{n}}{ }^{-}$ deserves special attention as it is the basis of the deep blue ultramarine pigments based on lazurite. ${ }^{10}$ Lapis lazuli being the rock mined as early as the 3rd millennium BC.

The present work focuses on yeelimite, $\mathrm{Ca}_{4}\left[\mathrm{Al}_{6} \mathrm{O}_{12}\right] \mathrm{SO}_{4}$, that can be described as a sodalite with $\mathrm{M}=\mathrm{Ca}, \mathrm{T}=\mathrm{Al}$ and $\mathrm{X}=\mathrm{SO}_{4}$, crystallizing as a tectoaluminosilicate sodalite structure. However, the fine details of the crystal structure of stoichiometric yeelimite at room temperature are 
controversial, as has been reported to be cubic ${ }^{11}$ tetragonal $^{12}$ and orthorhombic ${ }^{13}$. In addition to the compositional variability, the flexible sodalite framework can accommodate relatively large strains, able to vary its volume via cooperative rotations or tilts of the $\mathrm{TO}_{4}$ tetrahedra in order to match the size of the cage ions. Consequently, sodalites can have $\mathrm{Si} / \mathrm{Al}$ ratios ranging from $\infty$, for a pure silica framework, ${ }^{14}$ to zero, for a pure alumina one, like yeelimite. We note that in zeolite chemistry a $\mathrm{Si} / \mathrm{Al}$ less than one violates the well-known Loewenstein rule, which forbids Al-O-Al connectivity. ${ }^{15}$ Furthermore, yeelimite has the largest tetrahedral cage tiltangle determined so far for any aluminate sodalite. ${ }^{11 a}$ The formation of stoichiometric $\mathrm{Ca}_{4}\left[\mathrm{Al}_{6} \mathrm{O}_{12}\right] \mathrm{SO}_{4}$ is reported to be difficult, due to $\mathrm{CaSO}_{4}$ decomposition ${ }^{16}$, but can be prepared by firing a stoichiometric mixture of oxides and gypsum at $1300^{\circ} \mathrm{C} .{ }^{17}$ Yeelimite has also been used as starting material for the in-situ preparation of sulfide, $\mathrm{Ca}_{4}\left[\mathrm{Al}_{6} \mathrm{O}_{12}\right] \mathrm{S}$, under reducing conditions. ${ }^{18} \mathrm{~A}$ similar reaction allows to obtain $\mathrm{Sr}_{4}\left[\mathrm{Al}_{6} \mathrm{O}_{12}\right]$ Se from $\mathrm{Sr}_{4}\left[\mathrm{Al}_{6} \mathrm{O}_{12}\right] \mathrm{SeO}_{3}$. ${ }^{19}$

Members of the aluminate sodalite family, with $\mathrm{XO}_{4}$ anions, undergo reversible structural phase transitions at moderate temperatures. $^{20}$ The temperatures, crystal structure evolution, and associated enthalpies of the transitions have been reviewed. $^{21}$ The phase transitions are ferroic and occur at the boundary of the Brillouin zone, a fact that accounts for the formation of complicated superstructures and for frequentlyfound pseudomerohedral twinning. ${ }^{22}$ Finally and to the best of our knowledge, there is no report dealing with atomistic simulations of pure-alumina sodalites. There are some theoretical works on $\mathrm{Al} / \mathrm{Si}$ sodalites and we highlight that on $\mathrm{Na}_{3}\left[\mathrm{Al}_{3} \mathrm{Si}_{3} \mathrm{O}_{12}\right]$ where molecular simulation tools (empirical energy force field and quantum calculations) were used to study this sodalite with empty-anions cages. ${ }^{23}$

Yeelimite is the most important phase in calcium sulfoaluminate cements (CSA), which are very promising environmentally-friendly materials, addressing the major concern of the cement industry's environmental impact through $\mathrm{CO}_{2}$ emissions. On average, for every ton of ordinary Portland cement (OPC) produced, 0.97 tons of $\mathrm{CO}_{2}$ are released into the atmosphere, with the cement industry contributing around 6\% of all anthropogenic $\mathrm{CO}_{2}$ emissions translating into approximately $4 \%$ of the planet's global warming. ${ }^{24}$ By comparison, CSA cements are produced with significantly lower $\mathrm{CO}_{2}$ emissions relative to $\mathrm{OPC}^{25,26}$, achieved through the use of fewer carbonated raw-materials and a reduced clinkerization temperature. CSA cements are also relatively friable after firing and consequently require less energy to be ground. These new cements contain a different chemical composition to traditionally-used OPC products and are the subject of intense research as a reduction of $30-35 \%$ of $\mathrm{CO}_{2}$ emissions may be attained. ${ }^{25}$ During the 1970s, CSA cements were introduced into the Chinese market as a result of the high-performing and dimensionally-stable cementitious matrices developed by China Building Materials Academy. ${ }^{27}$ In Europe, the use of CSA cements is limited by the lack of standards concerning special cements derived from nonPortland clinkers. Nevertheless, the manufacture of CSA cements has recently been started by several European companies. Moreover, interesting new CSA-related cements cements are being developed, such as dicalcium silicate (belite) sulfoaluminate cements, known as sulfobelite cements. ${ }^{25,28}$
Although CSA cements have variable compositions, all of them contain yeelimite, ${ }^{29} \mathrm{Ca}_{4}\left[\mathrm{Al}_{6} \mathrm{O}_{12}\right] \mathrm{SO}_{4}$ (also called Klein's salt), as their main phase. These cements usually contain other such as belite, tetracalcium aluminoferrate, anhydrite, gehlenite or mayenite. Commercial CSA cements have special properties such as early-age high-strength development ${ }^{30,31}$. These cements can be used alone ${ }^{32}$ or in combination with other cements to provide an improved early resistance, reduced shrinkage, high impermeability, and a strong resistance to sulfate attack, relative to their OPC counterparts. ${ }^{33}$ Yeelimite is also included ( 25 wt.\%) in sulfobelite cements ${ }^{26,28,34}$ which contain the main phase belite.

Hence, the structure of yeelimite is important from basic and applied research point of views. Therefore, the objective of this study is to firmly establish the crystal structure of yeelimite. This was achieved by joint Rietveld refinement using laboratory X-ray and neutron powder diffraction data in conjunction with chemical soft-constraints. Furthermore, the stability of this special zeolite framework, containing only aluminum at the tetrahedral sites, was also studied by atomistic simulation. Finally, the temperature-induced phase transition of yeelimite was characterized.

\section{EXPERIMENTAL SECTION}

Sample preparation. $\mathrm{Ca}_{4}\left[\mathrm{Al}_{6} \mathrm{O}_{12}\right] \mathrm{SO}_{4}$ was synthesized following the methodology reported by Winnefeld et al., ${ }^{17}$ using $\mathrm{CaCO}_{3}$ (99.95\%, Alfa Aesar), $\mathrm{Al}_{2} \mathrm{O}_{3}$ (99.997\%, Alfa Aesar), and $\mathrm{CaSO}_{4} \cdot 2 \mathrm{H}_{2} \mathrm{O}$ (ground natural single-crystal from Málaga). The raw mixture was prepared with the amounts of starting materials needed for obtaining approximately $8 \mathrm{~g}$ of yeelimite. The mixture was ground for 1 hour in an agate mortar with ethanol. The resulting powders were pelletized (20 mm diameter) and heated at $1300^{\circ} \mathrm{C}$ for 4 hours (heating rate of $5{ }^{\circ} \mathrm{C} / \mathrm{min}$ ) before being slowly cooled.

Laboratory X-Ray powder diffraction (LXRPD). LXRPD data were recorded on an X'Pert MDP PRO diffractometer (PANalytical) equipped with a Ge (111) primary monochromator, using strictly monochromatic $\mathrm{CuK} \alpha_{1}$ radiation ( $\lambda=1.54059 \AA)$ and an X'Celerator detector. An overall measurement time of $\sim 4$ h per pattern was required for good statistics over the angular range 5.0 - $140.0^{\circ}(2 \theta)$ with a $0.017^{\circ}$ step size.

Neutron powder diffraction (NPD). NPD data were collected using Echidna, ${ }^{35}$ the high-resolution powder diffractometer at the Open Pool Australian Light-water (OPAL) reactor facility at the Australian Nuclear Science and Technology Organisation (ANSTO, Australia) using a wavelength of 1.62092(8) A determined using the NIST 660b standard reference material and 10 arc-minute secondary collimation. Data were collected over the angular range of $2.75-140^{\circ}(2 \theta)$ with a $0.05^{\circ}$ step size in an approach that allowed at least 2 detectors to pass through the same angular

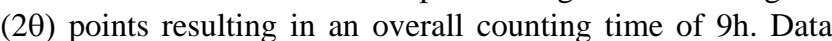
were intensity-corrected using local software.

Rietveld analysis of LXRPD and NPD data. Rietveld structural and quantitative phase analyses were done using the GSAS suite of programs and the EXPGUI graphic interface. ${ }^{36}$ Joint refinement using LXRPD and NPD data increases the probability of obtaining a unique and correct refinement solution. Further, the NPD and LXRPD data contain different 
contrast between elemental scattering lengths and factors, respectively. Notably, scattering from the oxygen contributes approximately $74 \%$ more to the NPD than the LXRPD data of yeelimite, which is of particular importance for the characterization of polyhedral tilting in the structure.

Final global optimized parameters were: background coefficients, zero-shift error, cell parameters, and peak shape parameters using a pseudo-Voigt function corrected for axial divergence. The atomic positional coordinates and isotropic atomic displacement parameters (ADPs) of yeelimite were optimized in the structural study.

To maintain chemically-reasonable geometries in the structure, i.e. aluminate and sulfate tetrahedra, $82 \mathrm{soft}$ constraints were used. These included for the $\mathrm{SO}_{4}: 4 \times \mathrm{S}-\mathrm{O}$ bond distances of $1.50(1) \AA$ and $6 \times \mathrm{O} \cdots \mathrm{O}$ interacting distances of 2.46(2) $\AA$, and for the $\mathrm{AlO}_{4}: 32 \times \mathrm{Al}-\mathrm{O}$ bond distances of $1.77(2) \AA$ and $40 \times \mathrm{O} \cdots \mathrm{O}$ distances of 2.90(4) $\AA$.

High Temperature LXRPD (HT-LXRPD). HT-LXRPD studies were carried out in the diffractometer described for the LXRPD collection using an Anton Paar HTK1200 camera under static air. Data were collected over temperature intervals ranging between 20 and $50{ }^{\circ} \mathrm{C}$, from $\mathrm{RT}$ to $800^{\circ} \mathrm{C}$ after a delay of $15 \mathrm{~min}$ to ensure thermal equilibration. Data were acquired over the angular range $17-45^{\circ}(2 \theta)$ with a step size of $0.017^{\circ}$, resulting in a 49 minute acquisition time per pattern. A higher quality pattern was collected at $800{ }^{\circ} \mathrm{C}$ in the angular range 5$100^{\circ}(2 \theta)$ with a step size of $0.017^{\circ}$, resulting in a $6 \mathrm{~h}$ data collection time. The sample was then cooled to RT where a final RT pattern was acquired.

Permittivity measurements. Electrical characterization was carried out on cylindrical pellets $(\sim 10 \mathrm{~mm}$ in diameter and $\sim 1$ mm thick) obtained by pressing $\sim 0.1 \mathrm{~g}$ of sample at $5000 \mathrm{MPa}$. The pellets were sintered at $1300{ }^{\circ} \mathrm{C}$ for $2 \mathrm{~h}$ after a heating rate of $5^{\circ} \mathrm{C} / \mathrm{min}$. Electrodes were made by coating opposite pellet faces with METALOR ${ }^{\circledR} 6082$ platinum paste and heating to $800^{\circ} \mathrm{C}$ at a rate of $5^{\circ} \mathrm{C} / \mathrm{min}$ for $15 \mathrm{~min}$ in air to decompose the paste and to harden the Pt residue. Impedance data were collected using a Hewlett-Packard 4284 A impedance analyzer over the frequency range $20 \mathrm{~Hz}-1 \mathrm{MHz}$ from 300 to $700^{\circ} \mathrm{C}$ at a heating rate of $10^{\circ} \mathrm{C} / \mathrm{min}$.

Differential scanning calorimetry (DSC). DSC data were recorded on a METTLER TOLEDO, model DSC 1, using a continuous flow of $\mathrm{N}_{2}$ at $20 \mathrm{~mL} / \mathrm{min}$ as protective gas. The sample was placed in a platinum crucible and heated from 30 to $700^{\circ} \mathrm{C}$ with a heating rate of $10^{\circ} \mathrm{C} / \mathrm{min}$, with the same rate for cooling.

Atomistic calculations Density functional theory (DFT) calculations were performed on periodic crystal structures using SIESTA code. ${ }^{37}$ Polarized double zeta numerical basis set for valence electrons and norm conserving pseudopotentials for atom cores were used. The exchangecorrelation functional is expanded within generalized gradient approximation (GGA) following Perdew-Burke-Ernzerhof scheme. ${ }^{38}$ We employed a mesh cutoff of 400 Rydberg where the Brillouin zone integrations converge for a mesh of $4 \times 4 \times 4$ k-points. The proposed structures were relaxed until the forces on atoms dropped below $0.02 \mathrm{eV} / \AA$. Note that both the lattice parameters and inner atomic positions were simultaneously optimized.

\section{Results and Discussion}

Synthesis. The synthesis yielded a sample consisting of 90.3(1) wt.\% stoichiometric yeelimite with minor amounts of three crystalline phases: 1.2 wt.\% of $\mathrm{Ca}_{3} \mathrm{Al}_{2} \mathrm{O}_{6}, 4.4(2)$ wt.\% of $\mathrm{CaAl}_{2} \mathrm{O}_{4}$, and 4.0(2) wt.\% of $\mathrm{Ca}_{12} \mathrm{Al}_{14} \mathrm{O}_{33}$. Furthermore, the thermodiffractometric study in open atmosphere (see below) showed the crystallization on heating of a small amount of $\mathrm{CaCO}_{3}$. Hence, a minor amount of amorphous calcium compound $\left[\mathrm{Ca}(\mathrm{OH})_{2} / \mathrm{CaO} / \mathrm{CaCO}_{3}\right]$ are likely present in the sample.

Structural study. The room-temperature high-resolution LXRPD pattern for stoichiometric yeelimite was autoindexed using TREOR ${ }^{39}$ in a tetragonal unit cell with dimensions $a=b=13.0416(9) \AA$, and $c=9.1701(7) \AA$, yielding a cell volume of $1559.7(3) \AA^{3}$, with figures of merit of M20=26 and F20=41 (0.009043, 54).

Thus, the tetragonal structural description, ${ }^{12}$ with space group $P \underline{4} c 2$, was used as a starting model for the joint Rietveld refinement. However, the fits were poor even also when the atomic parameters were refined, leading us to abandon this symmetry choice. Table 1 gives the figures of merit obtained during the joint Rietveld analysis using this tetragonal structural description.

As the recorded pattern contains clearly split diffraction peaks, the cubic sodalite structure was not tested, with the orthorhombic structural description ${ }^{13}$ which has $a \approx b$ unit cell parameters tested instead. Therefore, Table 1 also gives the starting and final (refined) figures of merit for the joint Rietveld refinements. Final Rietveld statistics details are given in Table S1. Figure 1 shows the final LXRPD and NPD Rietveld plots using the orthorhombic structure. The structure reported by Calos et al. ${ }^{13}$, has space group $P c c 2$ with the asymmetric unit containing 29 fully occupied and crystallographically-independent sites: $4 \mathrm{Ca}$ in general positions, $1 \mathrm{Si}$ in a general position; $8 \mathrm{Al}$ (4 in special and 4 in general positions), and $16 \mathrm{O}$ in general positions. Despite the increased observations/refined parameters ratio gained through use of the joint refinement, chemically unrealistic interatomic distances were obtained in the initial result. The introduction of soft constraints, as detailed in the experimental section, resulted in the final refined unit cell parameters $a=13.0356(7) \AA$, $b=13.0350(7) \AA$, and $c=9.1677(2) \AA$, yielding a cell volume of 1557.78(6) $\AA^{3}$. The isotropic ADPs were refined independently and these and other final refined atomic parameters are given in the supporting information (Table S2) along with relevant bond distances and angles (Table S3). The CIF file was also deposited.

Table 1. Figures of merit (\%) for the joint Rietveld refinement using LXRPD and NPD data of previouslyreported tetragonal and orthorhombic structures, shown before and after atomic parameter refinement.

\begin{tabular}{ccccc}
\hline & $\begin{array}{c}\text { Tetragonal } \\
\text { (ref. 12) }\end{array}$ & $\begin{array}{c}\text { Tetragonal } \\
\text { (refined) }\end{array}$ & $\begin{array}{c}\text { Orthorhombic } \\
\text { (ref. 13) }\end{array}$ & $\begin{array}{c}\text { Orthorhombic } \\
\text { (refined) }\end{array}$ \\
\hline$* \mathrm{R}_{\text {WP-XRD }}$ & 39.4 & 13.6 & 17.1 & 13.6 \\
$\mathrm{R}_{\text {F-XRD }}$ & 38.2 & 6.8 & 14.6 & 5.5 \\
$* \mathrm{R}_{\text {WP-NPD }}$ & 16.0 & 6.6 & 6.5 & 5.4 \\
$\mathrm{R}_{\text {F-NPD }}$ & 16.7 & 5.8 & 8.3 & 4.7 \\
\hline
\end{tabular}

*Fitted values 
The crystal structure of yeelimite is composed of an isolated $\mathrm{SO}_{4}$ tetrahedron in the center of a cage of corner sharing Al$\mathrm{O}_{4}$. The relatively high ADPs obtained for $\mathrm{S}$ and O1-O4, forming the sulfate group, indicate disorder of these anions within the cages ${ }^{2 a}$

Theoretical study. Depending on the input structure, our DFT calculations resulted in simulation found different phases, the energy of which is plotted against cell volume in Figure 2. When the initial structures were cubic ${ }^{11 a}$ or orthorhombic (this work), the calculations converged to the corresponding cubic $(\mathrm{I} \underline{4} 3 \mathrm{~m})$ and orthorhombic (Pcc2) structures, given in Table 2. Energy minimization of the tetragonal $P \underline{4} c 2$ lattice proposed experimentally by Peixing et al., ${ }^{12}$ resulted in convergence to the orthorhombic Pcc2 structure. Our calculated cubic and orthorhombic phases agree well with our experimental data, despite the relatively larger unit cell volumes obtained computationally, an expected result of the GGA-DFT approach. Because perfect cubic symmetry in yeelimite and related compounds is disputed, ${ }^{21}$ we performed calculations for lattices with lower symmetry but of the size of the basic sodalite cell, including one tetragonal $I \underline{4}$ and another monoclinic $\mathrm{Cm}$ space groups, (Table 2). The CIF file for the four calculated structures are included in the supporting information.
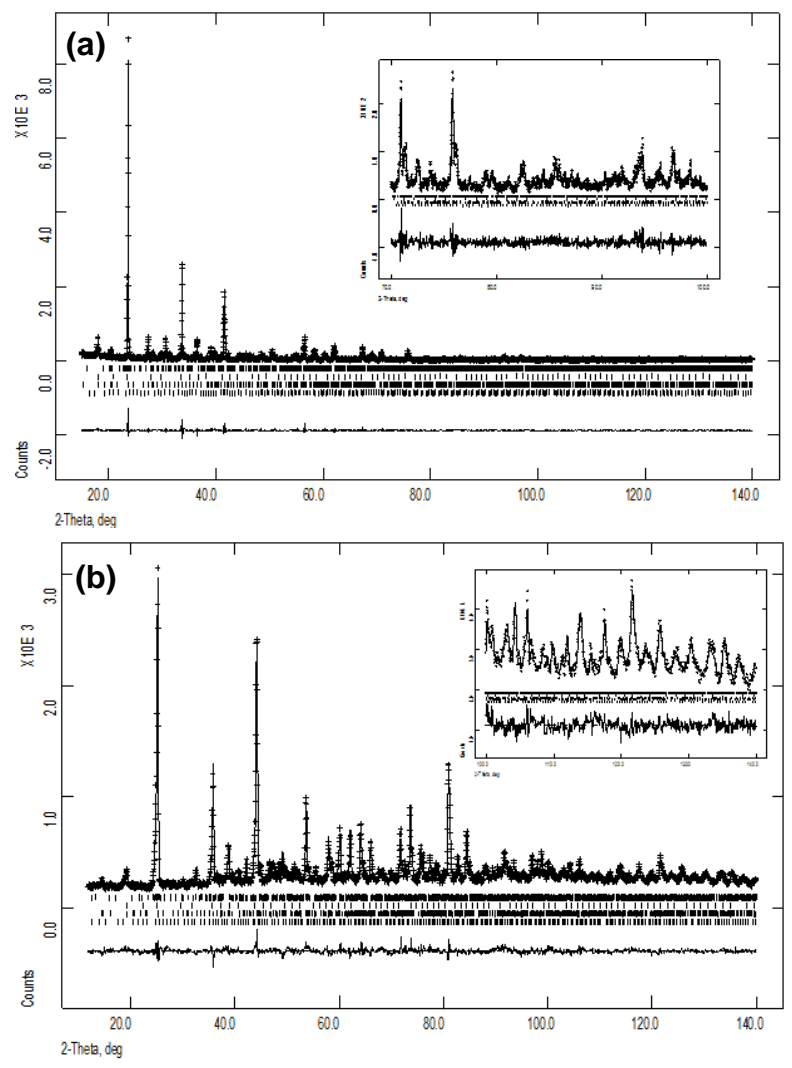

Figure 1. (a) LXRPD and (b) NPD Rietveld plots for $\mathrm{Ca}_{4}\left[\mathrm{Al}_{6} \mathrm{O}_{12}\right] \mathrm{SO}_{4}$. Insets detail the high-angle range.

The phase stability was evaluated by comparing the difference between the energy and that of the ground-state phase, the orthorhombic structure (Table 2). The energies of several cell volumes around the equilibrium cell were obtained and fitted to the third-order Murnaghan equation of state. ${ }^{40}$ The total energy as a function of the cell volume is shown in Figure 2. The theoretical bulk moduli are also listed in Table 2, which likely encourages further experimental studies of elastic properties in the phases of yeelimite.

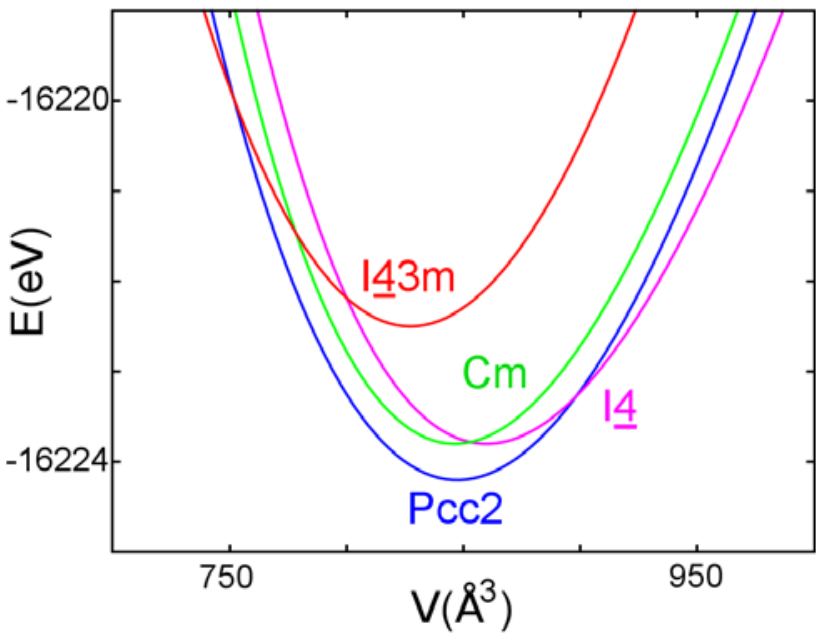

Figure 2. Calculated energy vs. volume, fitted to Murnaghan equation for different yeelimite phases. Energy is normalized per content of single unit cell, $\mathrm{Ca}_{8}\left[\mathrm{Al}_{12} \mathrm{O}_{24}\right] 2 \mathrm{SO}_{4}$.

Table 2. Selected results from DFT calculations for different yeelimite phases. Structural data for the lattice, bulk moduli, and relative energy stabilities $(\Delta \mathrm{E})$ normalized per single unit cell $\mathrm{Ca}_{8}\left[\mathrm{Al}_{12} \mathrm{O}_{24}\right] 2 \mathrm{SO}_{4}$ are also shown.

\begin{tabular}{|c|c|c|c|c|c|c|}
\hline Phase & $\begin{array}{c}\text { Lattice } \\
\text { axis/angle }\end{array}$ & $\begin{array}{c}\text { Length, angle } \\
\left(\AA,{ }^{\circ}\right)\end{array}$ & $\begin{array}{c}\mathrm{V} \\
\left(\AA^{3}\right)\end{array}$ & $\begin{array}{c}\rho \\
\left(\mathrm{g} / \mathrm{cm}^{3}\right)\end{array}$ & $\begin{array}{c}\mathrm{K} \\
(\mathrm{GPa})\end{array}$ & $\begin{array}{l}\Delta \mathrm{E} \\
(\mathrm{eV})\end{array}$ \\
\hline \multirow{3}{*}{ Pcc2 } & $a$ & 13.397 & 1692.68 & 2.39 & 105.7 & 0.00 \\
\hline & $b$ & 13.445 & & & & \\
\hline & c & 9.398 & & & & \\
\hline \multirow{2}{*}{$I \underline{4}$} & $a$ & 9.505 & 859.77 & 2.36 & 107.8 & 0.33 \\
\hline & c & 9.516 & & & & \\
\hline \multirow{4}{*}{$\mathrm{Cm}$} & $a$ & 9.445 & 845.60 & 2.40 & 114.9 & 0.41 \\
\hline & $b$ & 13.333 & & & & \\
\hline & c & 8.246 & & & & \\
\hline & $\beta$ & 54.5 & & & & \\
\hline $\mathrm{I} 43 \mathrm{~m}$ & $a$ & 9.385 & 826.55 & 2.45 & 109.4 & 1.65 \\
\hline
\end{tabular}

On the basis of the theoretical calculation results shown in Table 2 and Figure 2, several conclusions regarding phase transitions of yeelimite can be drawn. Firstly, the most stable phase found was the orthorhombic Pcc2 structure, in agreement with our experimental results. The tetragonal $I \underline{4}$ and monoclinic $\mathrm{Cm}$ phases are predicted to have similar stabilities, both being about $0.4 \mathrm{eV}$ above that of the orthorhombic Pcc2 structure. The ideal cubic $I \underline{4} 3 \mathrm{~m}$ structure is $1.6 \mathrm{eV}$ less stable than the orthorhombic phase. As the curves in Figure 2 for the $I \underline{4} 3 \mathrm{~m}$ and $\mathrm{Pcc} 2$ phases intersect, a pressure-induced transition of yeelimite from $P c c 2$ to $I \underline{4} 3 m$ may occur. Similarly, the possibility for a phase transition from $P c c 2$ to $I \underline{4}$ is also indicated, noting that the $I \underline{4}$ tetragonal phase should not be 
confused with the previously-reported $P \underline{4} c 2$ structure. ${ }^{12}$ On the basis of our theoretical study, we suggest that the $P \underline{4} c 2$ structural description is a poor representation of the groundstate $P c c 2$ structure. Notably, the $I \underline{4}$ tetragonal structure has an expanded volume with respect to the Pcc2 phase. The lattice constants of the $I \underline{4}$ phase are very close to the cubic one, with $c \approx a$. Hence, the tetragonal $I \underline{4}$ structure provides a good description of the experimentally-measured highertemperature phase containing a pseudocubic lattice. This observation is consistent with that of Depmeier, ${ }^{41}$ who noticed that yeelimite-like sodalites are unlikely to have perfect cubic symmetry as a result of the tendency of the $\mathrm{XO}_{4}$ anions to rotate with respect to the symmetry axis of cubic unit cell.

The phase transitions occurring in yeelimite (Figure 3) can be qualitatively understood on the basis of Pauling rules. ${ }^{42}$ The cubic structure is found to be unstable as a result of the face sharing of the $\mathrm{SO}_{4}$ tetrahedra and $\mathrm{CaO}_{6}$ octahedra in the most densely-packed structure. As the volume expands, the structure breaks cubic symmetry, reducing the energy (Figure 2 ). This is demonstrated in the tetragonal $I \underline{4}$ and orthorhombic Pcc2 phases, which have $\mathrm{SO}_{4}$ and $\mathrm{AlO}_{4}$ tetrahedra that only share edges and vertices with $\mathrm{CaO}_{x}$ polyhedra (Figure 3). The higher stability of the $P c c 2$ phase relative to the $I 4$ phase is attributed to a longer average Al-Ca distance (Table 3 and Table S3).

Table 3. Calculated structural data of cationic sites in the I43m, I4 and Pcc2 phases of yeelimite, including the number of crystallographic sites for each cation $\left(N_{A}\right)$, the average nearest-neighbor distance between two elements $\left(R_{A-B}, \AA\right)$, and the coordination number of an element $\left(\mathrm{CN}_{\mathrm{A}-\mathrm{B}}\right)$. Inter-cationic distances below $4 \AA$ are considered.

\begin{tabular}{ccccccccccc}
\hline Phase & $\begin{array}{c}\mathrm{N}_{\mathrm{C}} \\
\mathrm{a}\end{array}$ & $\begin{array}{c}\mathrm{N}_{\mathrm{A}} \\
1\end{array}$ & $\begin{array}{c}\mathrm{N} \\
\mathrm{s}\end{array}$ & $\mathrm{R}_{\mathrm{S}-\mathrm{Ca}}$ & $\mathrm{CN}_{\mathrm{S}-\mathrm{Ca}}$ & $\begin{array}{c}\mathrm{CN}_{\mathrm{Ca}-} \\
\mathrm{s}\end{array}$ & $\mathrm{R}_{\text {Ca-Al }}$ & $\mathrm{CN}_{\mathrm{Ca}-\mathrm{Al}}$ & $\mathrm{R}_{\mathrm{Al}-\mathrm{Ca}}$ & $\mathrm{CN}_{\mathrm{Al}-\mathrm{Ca}}$ \\
\hline$I \underline{4} 3 m$ & 1 & 1 & 1 & 3.069 & 4 & 1 & 3.464 & 6 & 3.464 & 4 \\
\hline$I \underline{4}$ & 1 & 3 & 1 & 3.580 & 4 & 1 & 3.408 & 6 & 3.408 & 4 \\
\hline$P c c 2$ & 4 & 8 & 1 & 3.493 & 5 & $1.25^{1}$ & 3.439 & 6 & 3.475 & 4 \\
\hline
\end{tabular}

${ }^{1}$ Three Ca sites have $\mathrm{CN}_{\mathrm{Ca}-\mathrm{S}}=1$ and the fourth has $\mathrm{CN}_{\mathrm{Ca}-\mathrm{S}}=2$.

Application of the structural study to the analysis of a CSA cement. The refined orthorhombic structure was used to describe a commercial CSA cement which contained large amounts of yeelimite. ${ }^{32}$ The chemical analysis of this cement (X-ray fluoresce data) was reported in that publication. Rietveld refinement strategy is detailed in supporting information. $\mathrm{R}_{\mathrm{F}}$ values from the Rietveld refinement of the $\mathrm{Ca}_{4}\left[\mathrm{Al}_{6} \mathrm{O}_{12}\right] \mathrm{SO}_{4}$ phase were $6.9 \%$ and $4.8 \%$ for the reported orthorhombic structure ${ }^{13}$ and for that given here, respectively. Furthermore, the figure of merit for the whole pattern, $\mathrm{R}_{\mathrm{wP}}$, was smaller for the structure reported here, $7.6 \%$, than for that using the previously-reported ${ }^{13}$ structure, $8.7 \%$. The structure presented in the present study will allow more accurate mineralogical phase analysis of yeelimite-containing cements. The quantitative phase analyses results for this cement are given in Table S4, also including ICSD collection codes for all the phases. The Rietveld plot, fitted using the refined yeelimite structure, is also given in Figure S1. (a)
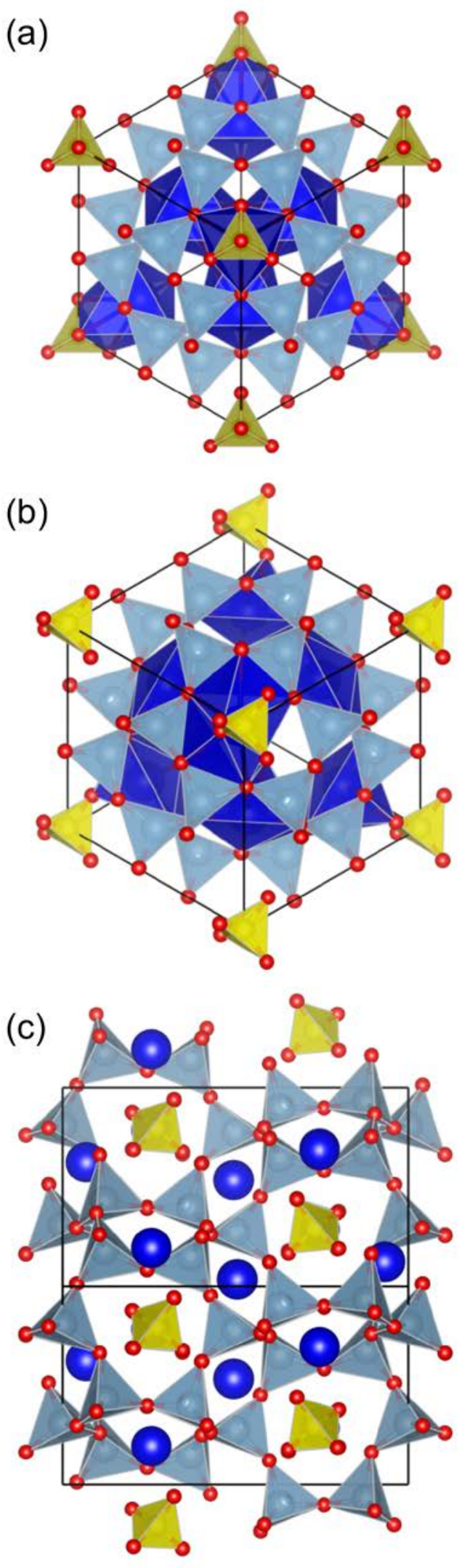

Figure 3. Calculated crystal structures of yeelimite phases: (a) cubic $I \underline{4} 3 m$, (b) tetragonal $I \underline{4}$, and (c) orthorhombic Pcc2. Ca denoted within dark-blue prisms, Al within light-blue tetrahedra, 
$\mathrm{S}$ within yellow tetrahedra, and $\mathrm{O}$ are red. $\mathrm{CaO}$ bonds are omitted in (c) for clarity.

High-temperature phase transition. A phase transition of yeelimite on heating was reported, although it has not been studied in detail. ${ }^{21}$ We determine here the transition temperature using DSC and permittivity measurements (Figure 4). From DSC, the phase transition takes place at $480{ }^{\circ} \mathrm{C}$ on heating and at $470{ }^{\circ} \mathrm{C}$ on cooling. The relatively small hysteresis obtained is likely a result of differences in the heating/cooling rate, particularly as the permittivity study identifies the phase transition at $470{ }^{\circ} \mathrm{C}$ on heating. These results agree quite well with the reported value of $464^{\circ} \mathrm{C} .^{21}$

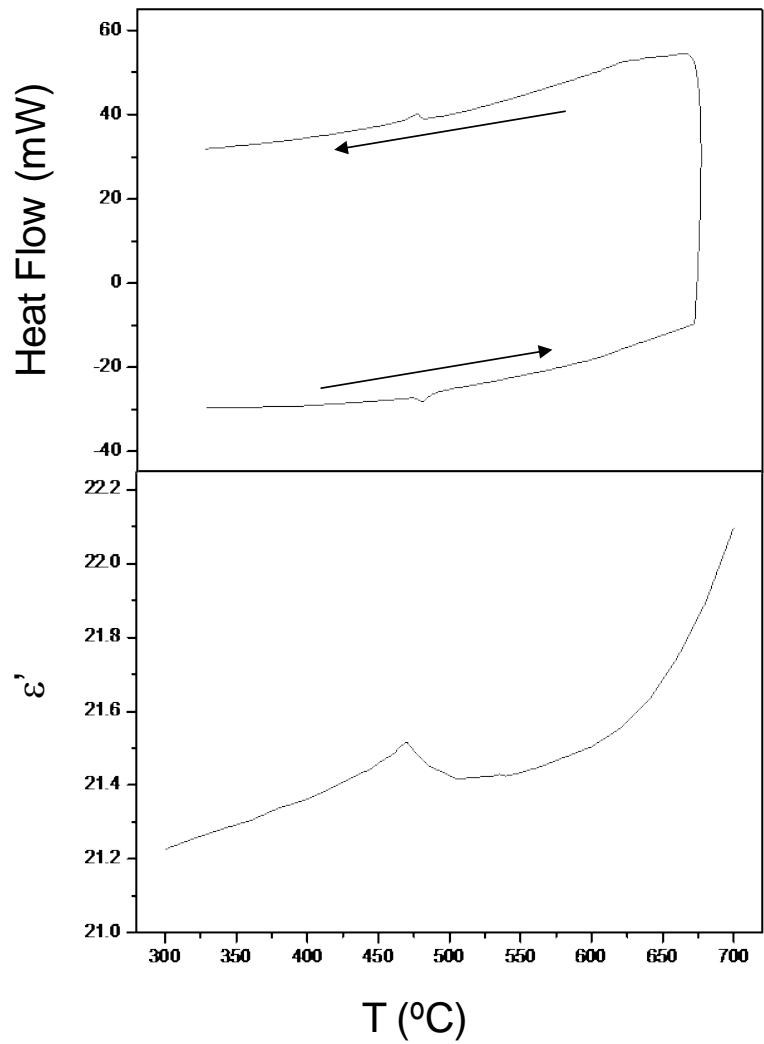

Figure 4. DSC curves on heating and cooling (top) and permittivity signal (bottom) for pressed powder of stoichiometric $\mathrm{Ca}_{4}\left[\mathrm{Al}_{6} \mathrm{O}_{12}\right] \mathrm{SO}_{4}$.

A thermodiffractometric LXRPD study, up to $800^{\circ} \mathrm{C}$, has been performed for yeelimite. Figure 5 shows the evolution of the patterns with temperature, in which some reflections have been labeled. Arrows in Figure 5 stand for the orthorhombic superstructure reflections that disappeared for temperatures above $470{ }^{\circ} \mathrm{C}$ and they re-appeared on cooling. It must also be highlighted that a reflection appears at $\sim 29^{\circ}(2 \theta)$ which growths with temperature and it vanishes at $700^{\circ} \mathrm{C}$ (star). This reflection corresponds to $\mathrm{d}_{214}$ of crystalline calcite, $\mathrm{CaCO}_{3}$. Decomposition of calcium carbonate takes place slightly below $700^{\circ} \mathrm{C}$ and the diffraction peaks of crystalline $\mathrm{CaO}$ appears (solid circle), which it is still present at final RT pattern, see Figure 5.

The most interesting structural development in the thermodiffraction study is the appearance of a diffraction peak near $25.5^{\circ}(2 \theta)$ above $500{ }^{\circ} \mathrm{C}$ (solid triangle). This peak is not accounted for by any crystalline phase within this chemical system and cannot be indexed by a commensurate supercell of the basic cubic sodalite substructure of $\mathrm{Ca}_{4}\left[\mathrm{Al}_{6} \mathrm{O}_{12}\right] \mathrm{SO}_{4}$. Unfortunately a unique propagation vector cannot be determined from a single peak. For instance the propagation vectors $\mathrm{k} 1=(\mathrm{v} 100)$ with $\mathrm{v} 1=0.226(1), \mathrm{k} 2=(\mathrm{v} 2 \mathrm{v} 20)$ with $\mathrm{v} 2=0.353(1)$, and $\mathrm{k} 3=(\mathrm{v} 3 \mathrm{v} 3 \mathrm{v} 3)$ with $\mathrm{v} 3=0.565(1)$ all predict a 211 reflection as the most intense satellite at the $25.5^{\circ}(2 \theta)$ position. Therefore, whilst we cannot report a unique propagation vector for the incommensurate structure, we note that structurallymodulated phases are relatively common in aluminate sodalities. $^{43}$

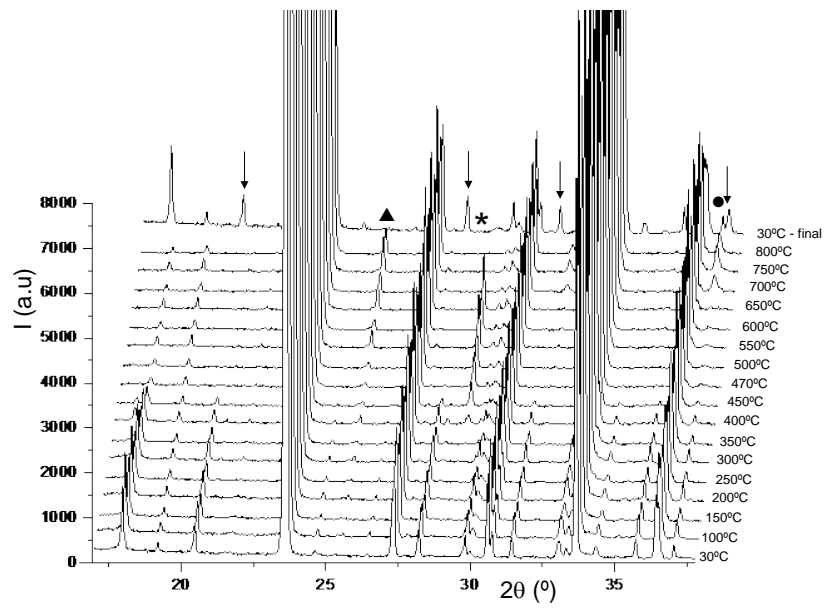

Figure 5. Selected range of the thermodiffractometric study for $\mathrm{Ca}_{4}\left[\mathrm{Al}_{6} \mathrm{O}_{12}\right] \mathrm{SO}_{4}$. For the meaning of the symbols, see the text.

We study in detail the low- to high-symmetry phase transition on heating, with a selected view of the thermodiffractometric study shown in Figure 6. This figure clearly shows the transition of the orthorhombic (with a doubled unit cell) to a higher symmetry phase, the latter being likely pseudo-cubic or cubic. As discussed above, this high temperature (high-symmetry) yeelimite structure is likely incommensurate in nature due to the mismatch of disordered sulfate groups with the sodalite framework. This phase transition is likely related to that obtained in the theoretical study between the smaller-volume Pcc2 and larger-volume $I \underline{4}$ phases.

Results showing the unit cell parameter(s) and volume obtained from Rietveld analysis of the HT-LXRPD patterns for the orthorhombic Pcc2 and cubic $I \underline{4} 3 \mathrm{~m}$ phases as function of temperature are shown in Figure 7 . The cell parameters and volume for the low-temperature orthorhombic polymorph have been plotted as $a_{0} / \sqrt{2}, b_{0} / \sqrt{2}$, and $\mathrm{V}_{0} / 2$ for ease comparison with cubic 'average' values. The crystal structure used to fit the higher-temperature cubic phase was derived from the $I \underline{4} 3 \mathrm{~m}$ phase reported by Saalfeld and Depmeier, ${ }^{11 a}$ with the $I \underline{4}$ structure obtained from the DFT calculation providing a poorer description.

The unit cell parameter behavior observed during the phase transition is that expected for the evolution of a lowersymmetry phase due to long-range sulfate ordering to a higher-symmetry phase where sulfate anions display disorder, likely due to rotation. Further atomistic studies are needed to 
fully characterize the local environment and anion arrangement in the higher-temperature structure. Figure S2 shows the Rietveld plot for yeelimite at $800{ }^{\circ} \mathrm{C}$ as an example. We note that the fit is produced using an approximately-cubic $I \underline{4} 3 \mathrm{~m}$ substructure that does not index the reflection observed at $25.5^{\circ}(2 \theta)$ (solid triangle in Figure 5). As this is an approximate average substructure, we do not report the atomic coordinates.

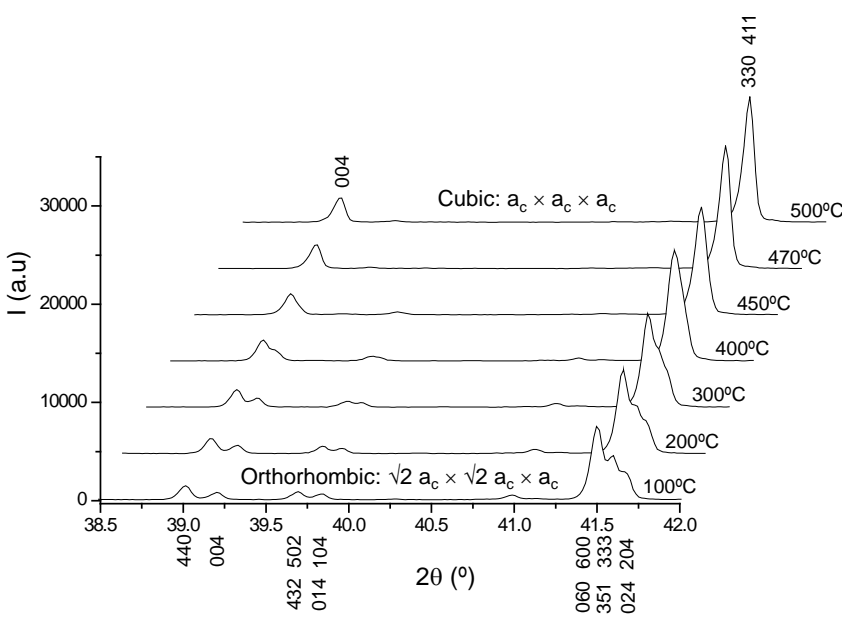

Figure 6. Temperature-dependence LXRPD patterns for $\mathrm{Ca}_{4}\left[\mathrm{Al}_{6} \mathrm{O}_{12}\right] \mathrm{SO}_{4}$ shown over a selected range with Miller indexes displayed for the orthorhombic (bottom) and cubic (top) phases.

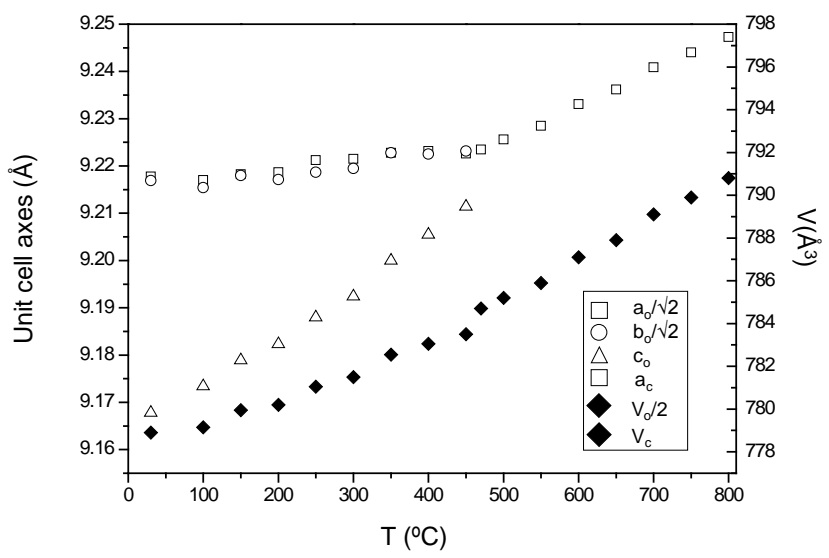

Figure 7. Refined unit cell parameters (open symbols) and volume (solid symbol) for the orthorhombic (from RT to $450{ }^{\circ} \mathrm{C}$ ) and cubic (470 to $800{ }^{\circ} \mathrm{C}$ ) $\mathrm{Ca}_{4}\left[\mathrm{Al}_{6} \mathrm{O}_{12}\right] \mathrm{SO}_{4}$ phases as a function of temperature. Errors are smaller than the points.

\section{CONCLUSION}

The room-temperature crystal structure of stoichiometric yeelimite, $\mathrm{Ca}_{4}\left[\mathrm{Al}_{6} \mathrm{O}_{12}\right] \mathrm{SO}_{4}$, has been studied by powder diffraction and atomistic calculations. Yeelimite $\sqrt{2} a \times \sqrt{2} a \times a$ superstructure of the cubic average-structure of sodalite. Although the metric of yeelimite is tetragonal $(a=b \neq c$ within the errors of the measurements), both experimental and theoretical studies firmly establish a lower symmetry phase, very likely in the acentric orthorhombic Pcc2 space group. The pseudosymmetry of the yeelimite phases complicate an experimental structural study, a complication that we overcome by employing joint Rietveld refinement using neutron and X-ray powder diffraction in conjunction with soft chemical-constraints, allowing a good structural description for stoichiometric yeelimite to be obtained. Our experimental results are complemented by density functional theory calculations which determine several further structures, with the lowest energy structure the $P c c 2$ orthorhombic phase in agreement with our experimental result. Temperature-dependent X-ray powder diffraction, differential scanning calorimetry, and permittivity data indicate a phase transition at $470{ }^{\circ} \mathrm{C}$ on heating from the lower temperature and symmetry phase to a higher-symmetry phase that is likely cubic or pseudo-cubic. Our X-ray powder diffraction results indicate that the crystal structure of the higher-temperature phase is probably incommensurate, with our theoretical study predicting a corresponding phase transition from orthorhombic to tetragonal, alongside the possibility of a pressure-induced phase transition. Finally, we show that the crystal structure of yeelimite that we report enables superior mineralogical phase analysis of a commercial calcium sulfoaluminate cement to that obtained using previously-reported structures.

\section{ASSOCIATED CONTENT}

Supporting Information. Description of the Rietveld strategy for quantitative phase analysis of CSA cement. CIF files for (i) the orthorhombic crystal structure of room-temperature $\mathrm{Ca}_{4}\left[\mathrm{Al}_{6} \mathrm{O}_{12}\right] \mathrm{SO}_{4}$ obtained from joint refinement using neutron and laboratory X-ray powder diffraction; and (ii) the four structures obtained using atomistic calculations in $I 43 \mathrm{~m}, I 4, P c c 2$, and $\mathrm{Cm}$ space groups. Table $\mathrm{S} 1$ includes final statistics of joint Rietveld refinement for orthorhombic yeelimite. Table S2 gives the final atomic positional and displacement parameters for the orthorhombic experimentally-determined Pcc2 structure, with the corresponding bond distances and angles shown in Table S3. Table S4 shows the quantitative phase analysis results for a commercial calcium sulfoaluminate cement using two orthorhombic structures for yeelimite: (i) previously-reported; (ii) from this study. Figure S1 shows the Rietveld plot for the analyzed CSA cement and Figure S2 shows the Rietveld plot for stoichiometric yeelimite at $800{ }^{\circ} \mathrm{C}$.

\section{AUTHOR INFORMATION}

\section{Corresponding Author}

*g_aranda@uma.es (M.A.G.A.)

\section{Author Contributions}

This is part of the Ph.D. of Ms. Ana Cuesta. The manuscript was written through contributions of all authors. All authors have given approval to the final version of the manuscript.

\section{Funding Sources}

The work at UMA was funded by MAT2010-16213 research grant (Spain) which is co-funded by FEDER. The work at the DIPC was supported by the Basque Departamento de Educación and the UPV/EHU (Grant No. IT-366-07), the Spanish Ministerio de Innovación, Ciencia y Tecnología (Grant Nos. TEC200768065-C03-03 and FIS2010-19609-C02-02), and the ETORTEK research program (NANO-IKER Grant No. IE11-304) funded by the Basque Departamento de Industria and the Diputación Foral de Guipuzcoa. 


\section{REFERENCES}

(1) Hurlbut, C. S.; Klein, C. Manual of Mineralogy, 20th ed., 1985.

(2) (a) Depmeier, W. Rev. Mineral. Geochem. 2005, 57, 203. (b) Fischer, R. X.; Baur, W. H. Z. Kristallogr. 2009, 224, 185.

(3) Leardini, L.; Martucci, A.; Cruciani, G. Microporous Mesoporous Mater. 2012, 151, 163.

(4) Setter, N.; Mendoza-Alvarez, M. E.; Depmeier, W.; Schmid, H. Ferroelectrics 1984, 56, 49.

(5) (a) Barrer, R. M. and Coler, J. F. J. Phys. Chem. Solids 1968, 29, 1755. (b) Srdanov, V. I.; Haug, K.; Metiu, H.; Stucky, G. D. J. Phys. Chem. 1992, 96, 9039.

(6) (a) Monnier, A.; Srdanov, V.; Stucky, G.; Metiu, H. J. Chem. Phys. 1994, 100, 6944. (b) Srdanov, V. I.; Stucky, G. D.; Lippmaa, E.; Engelhardt, G. Phys. Rev. Lett. 1998, 80, 2449. (c) Nakano, T.; Matsuura, M.; Hanazawa, A.; Hirota, K.; Nozue, Y. Phys. Rev. Lett. 2012, 109, 167208.

(7) (a) Ogura, M.; Morozumi, K.; Elangovan, S. P.; Tanada, H.; Ando, H.; Okubo, T. Appl. Catal., B, 2008, 77, 294. (b) Shanbhag, G. V.; Choi, M.; Kim, J.; Ryoo R. J. Catal. 2009, 264, 88. (c) Choi, M.; Lee, D.-H.; Na, K.; Yu, B.-W.; Ryoo, R. Angew. Chem., Int. Ed. 2009, 48, 3673. (d) Sachse, A.; Galarneau, A,; Di Renzo, F.; Fajula, F.; Coq, B. Chem. Mater. 2010, 22, 4123. (e) Goel, S.; Wu, Z.; Zones, S. I.; Iglesia, E. J. Am. Chem. Soc. 2012 134, 17688.

(8) Moran, K. L.; Harrison, W. T. A.; Kamber, I.; Gier, T. E.; Bu, X.; Herren, D.; Behrens, P.; Eckert, H.; Stucky, G. D. Chem. Mater. 1996, 8, 1930 .

(9) (a) Borgmann, C.; Sauer, J.; Jüstel, T.; Kynast, U.; Schüth, F. Adv. Mater. 1999, 11, 45. (b) Lezhnina, M.; Laeri, F.; Benmouhadi, L.; Kynast, U. Adv. Mater. 2006, 18, 280.

(10) Reinen, D.; Lindner, G. G. Chem. Soc. Rev. 1999, $28,75$.

(11) (a) Saalfeld, H.; Depmeier, W. Kristall und Technik 1972, 7, 229. (b) Wang, Y.G.; Ye, H.Q.; Kuo, K.H.; Feng, X.J.; Lao, G.L.; Long, S.Z. J. Mater. Sci. 1990, 25, 5147-5156.

(12) Peixing, Z; Yimin, C.; Piping, S.; Guanying, Z.; Wenmel, H.; Jiaguo, W. " The crystal structure of $\mathrm{C}_{4} \mathrm{~A}_{3}$ ? ” Proceeding of 9th International Congress on the Chemistry of Cement, Vol. 1, Tara Art Press, New Delhi, India 1992, pp.201-208.

(13) Calos, N.J.; Kennard, C.H.L.; Whittaker, A.K.; Davis, R.L. J. Solid State Chem. 1995, 119, 1.

(14) (a) Bibby, D. M.; Dale, M. P. Nature, 1985, 317, 157. (b) Moteki, T.; Chaikittisilp, W.; Shimojima, A.; Okubo, T. J. Am. Chem. Soc. 2008, 130, 15780.

(15) Loewenstein, W. Am. Mineral. 1954, 34, 92.

(16) Song, J-T. J. Am. Ceram. Soc. 2002, 85, 535.

(17) Winnefeld, F.; Barlag, S. J. Therm. Anal. Calorim. 2010, 101, 949.

(18) Brenchley, M.E.; Weller, M.T. J Mat. Chem. 1992, 2, 1003.

(19) Brenchley, M.E.; Weller, M.T. Chem. Mat. 1993, 5, 970.

(20) (a) Depmeier, W.; Bührer, W. Acta Crystallogr., Sect. B: Struct. Sci.1991. 47, 197. (b) Smaalen, S.V.; Dinnebier, R.; Katzke, H.; Depmeier; W. J. State Solid Chem. 1997, 129, 130. (c) Antao, S.M.; Hassan, I.; Parise, J.B. Can. Mineral. 2004, 42, 1047.

(21) Depmeier, W. Phys. Chem Miner. 1988, 15, 419.

(22) Depmeier, W. J. Inclusion Phenom. 1987, 5, 279.

(23) Moloy, E. C.; Cygan, R. T.; Bonhomme, F.; Teter, D. M.; Navrotsky, A. Chem. Mater. 2004, 16, 2121.

(24) Flatt, R.J.; Roussel, N.; Cheeseman, C.R. J. Eur. Ceram. Soc. 2012, 32, 2787.

(25) Aranda, M.A.G.; De la Torre, A.G. in Eco-efficient concrete; Pacheco-Torgal, F. Ed.; Jalali, S. Ed.; Labrincha, J. Ed.; Woodhead Publishing: Cambridge, 2013; 488.

(26) (a) Gartner, E. Cem. Concr. Res. 2004, 34, 1489. (b) Popescu, C.D.; Muntean, M.; Sharp, J.H. Cem. Concr. Compos. 2003, 25 689.

(27) Zhang, L.; Su, M.; Wang, Y. Adv. Cem. Res.. 1999, 11,15.

(28) Morin, V.; Walenta, G.; Gartner, E.; Termkhajornkit, P.; Baco, I.; Casabonne, J.M. Hydration of a Belite-Calcium Sulfoaluminate- Ferrite cement: Aether ${ }^{\mathrm{TM}}$, Proceedings of the 13th international Congress on the Chemistry of Cement, Madrid, Spain, 2011.

(29) Álvarez-Pinazo, G.; Cuesta, A.; García-Maté, M.; Santacruz, I.; De la Torre, A. G.; León-Reina, L.; Aranda; M. A. G. Cem. Concr. Res. 2012, 42, 960.
(30) Quillin, K. Cem. Concr. Res. 2001, 31, 1341.

(31) Glasser, F.P.; Zhang, L. Cem. Concr. Res. 2001, 31, 1881.

(32) García-Maté, M.; De la Torre, A. G.; Santacruz, I.; León-Reina, L.; M.A.G. Aranda. Cem. Concr. Compos. 2012, 34, 684.

(33) Qian, G.R.; Shi, J.; Cao, Y.L.; Xu, Y.F.; Chui, P.C. J. Hazard. Mater. 2008, 152, 196.

(34) Cuberos, A.J.M.; De la Torre, A.G.; Álvarez-Pinazo, G.; MartínSedeño, M.C.; Schollbach, K.; Pöllmann, H.; Aranda, M.A.G. Environ. Sci. Technol. 2010, 44, 6855.

(35) Liss, K.D.; Hunter, B.; Hagen, M.; Noakes, T.; Kennedy, S. Physica B 2006, 385-86, 1010 .

(36) (a) Larson A. C.; Von Dreele, R.B. General Structure Analysis System (GSAS), Los Alamos National Laboratory Report LAUR 86-748, 2004. (b) Toby, B.H. J. Appl. Crystallogr. 2001, 34, 210.

(37) Soler, J. M.; Artacho, E.; Gale, J. D.; García, A.; Junquera, J.; Ordejón, P.; Sánchez-Portal, D. J. Phys.: Condens. Matter 2002, 114, 2745.

(38) Perdew, J. P.; Burke, K.; Ernzerhof, M. Phys. Rev. Lett. 1996, 77, 3865.

(39) Werner, P.E.; Eriksson L.; Westdahl, M. J. Appl. Crystallogr. 1985, 18, 367.

(40) Murnaghan, F. D. Proc. Nat. Ac. Sci. 1944, 30, 244.

(41) Depmeier, W. Acta Crystallogr., Sect. B: Struct. Sci.1988, 44, 201.

(42) Pauling, L. J. Am. Chem. Soc. 1929, 51, 1010.

(43) Depmeier, W. J. Alloys Compd. 1992, 188, 21. 
TOC.

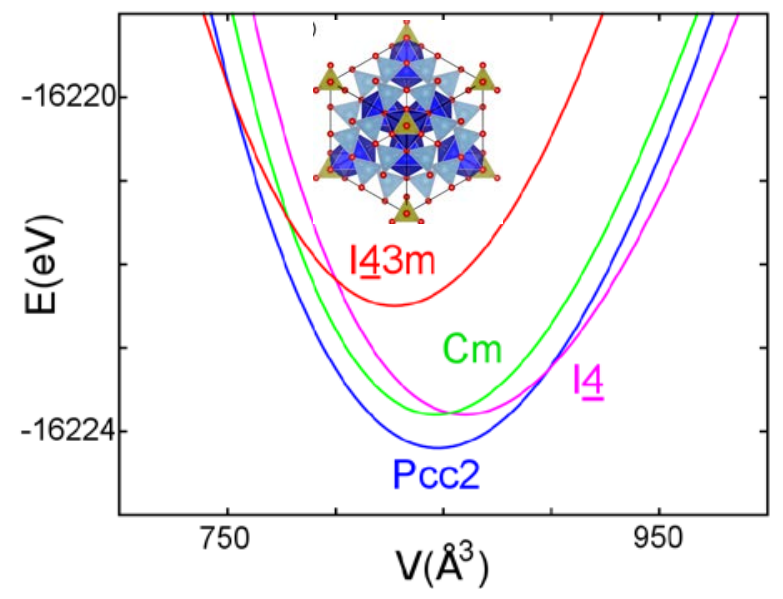




\section{Structure, atomistic simulations, and phase transition of yeelimite}

Ana Cuesta, ${ }^{\dagger}$ Angeles G. De la Torre, ${ }^{\dagger}$ Enrique R. Losilla, ${ }^{\dagger}$ Vanessa K. Peterson, ${ }^{\ddagger}$, Pawel Rejmak, Andrés Ayuela, ${ }^{\sharp, \$}$ Carlos Frontera, ${ }^{\&}$ and Miguel A.G. Aranda, ${ }^{,+\dagger, \pm}$

† Departamento de Química Inorgánica, Universidad de Málaga, Campus Teatinos s/n, Málaga-29071, Spain.

${ }^{\ddagger}$ Australian Nuclear Science and Technology Organisation, Lucas Heights, NSW 2234, Australia.

${ }^{*}$ Donostia International Physics Center (DIPC), p. Manuel de Lardizabal 4, Donostia-San Sebastián, Spain.

$\S$ Centro de Física de Materiales CFM-MPC CSIC-UPV/EHU, Departamento de Física de Materiales, Facultad de Químicas, Universidad del Pais Vasco UPV-EHU, 20018 Donostia-San Sebastián, Spain

\& ICMAB-CSIC, Campus universitari de Bellaterra, E-08193, Bellaterra, Barcelona, Spain.

${ }^{ \pm}$CELLS-Alba synchrotron, Carretera BP 1413, Km. 3.3, E-08290 Cerdanyola, Barcelona, Spain.

This supporting information includes:

Description of the Rietveld refinement strategy for CSA cement analysis.

Final overall refined parameters were: phase scale factors, 36 background coefficients of a linear interpolation function included in GSAS software, zero-shift error, unit cell parameters for all the phases, pseudo-voigt peak shape parameters for all the phases with contents larger than $1.5 \mathrm{wt} \%$ and preferred orientation coefficient for gypsum along [ $\left[\begin{array}{lll}0 & 1 & 0\end{array}\right]$ axis using MarchDollase algorithm ${ }^{1}$.

${ }^{1}$ Dollase, W.A. J. Appl. Crystallogr. 1986, 19, 267.

Table S1: Final Rietveld statistic data for the joint refinement using LXRPD and NPD data.

Table S2: Final (refined) atomic parameters (coordinates and isotropic displacement parameters) for stoichiometric yeelimite at room temperature.

Table S3: Interatomic distances and angles for stoichiometric yeelimite at room temperature.

Table S4. Rietveld quantitative phase analysis results for a commercial CSA cement using both the bibliographic and refined orthorhombic structure for yeelimite (reporting final Rietveld figures of merit). ICSD collection codes are also included.

Figure S1. Rietveld plot for the commercial CSA cement using this reported orthorhombic crystal structure for yeelimite, with peaks for a given phase labeled.

Figure S2. Rietveld plot for stoichiometric yeelimite at $800^{\circ} \mathrm{C}$. The average structure has been modeled in the cubic $I \underline{4} 3 m$ space group. Inset shows a detail in the high-angle region. 
Table S1: Final selected Rietveld statistic data for the joint refinement using LXRPD and NPD data.*

\begin{tabular}{lcc}
\hline & LXRPD & NPD \\
\hline $\mathrm{R}_{\mathrm{WP}} / \%$ & 13.6 & 5.4 \\
$\mathrm{R}_{\mathrm{p}} / \%$ & 10.1 & 4.4 \\
Overall $\mathrm{R}_{\mathrm{F}}{ }^{2} / \%$ & 8.8 & 7.7 \\
Number data points & 7645 & 3040 \\
$\begin{array}{l}\text { Overall number of } \\
\text { observed reflections }\end{array}$ & 5110 & 5060 \\
$\chi^{2} / \%$ & \multicolumn{2}{c}{3.8 (182 variables) } \\
\hline $\mathrm{R}_{\mathrm{WP}}$ and $\mathrm{R}_{\mathrm{P}}$ reported values are fitted data.
\end{tabular}

Table S2. Refined atomic coordinates and atomic isotropic displacement parameters (ADPs) for stoichiometric yeelimite at room temperature in the Pcc2 space group.

\begin{tabular}{ccccc} 
Atom & $\mathrm{x}$ & $\mathrm{y}$ & $\mathrm{z}$ & $\mathrm{ADPs} / \AA^{2}$ \\
\hline $\mathrm{S} 1$ & $0.2691(7)$ & $0.2693(7)$ & $0.9654(10)$ & $0.028(3)$ \\
$\mathrm{O} 1$ & $0.6790(12)$ & $0.2645(16)$ & $0.6111(12)$ & $0.099(8)$ \\
$\mathrm{O} 2$ & $0.8260(8)$ & $0.2042(9)$ & $0.4666(15)$ & $0.033(4)$ \\
$\mathrm{O} 3$ & $0.7590(15)$ & $0.3781(7)$ & $0.4296(22)$ & $0.103(8)$ \\
$\mathrm{O} 4$ & $0.6598(10)$ & $0.2280(14)$ & $0.3507(17)$ & $0.073(7)$ \\
$\mathrm{Ca} 1$ & $0.0627(11)$ & $0.2495(14)$ & $0.1554(17)$ & $0.020(4)$ \\
$\mathrm{Ca} 2$ & $0.2549(14)$ & $0.9417(12)$ & $0.2945(16)$ & $0.011(4)$ \\
$\mathrm{Ca} 3$ & $0.2591(16)$ & $0.5301(11)$ & $0.2196(13)$ & $0.035(4)$ \\
$\mathrm{Ca} 4$ & $0.4910(9)$ & $0.2548(13)$ & $0.2196(13)$ & $0.013(3)$ \\
$\mathrm{Al} 1$ & 0.5000 & 0.5000 & $0.2242(15)$ & $0.005(4)$ \\
$\mathrm{Al} 2$ & 0.5000 & 0.0000 & $0.2466(12)$ & $0.016(8)$ \\
$\mathrm{Al} 3$ & 0.0000 & 0.0000 & $0.2292(15)$ & $0.021(5)$ \\
$\mathrm{Al} 4$ & 0.0000 & 0.5000 & $0.2011(11)$ & $0.026(8)$ \\
$\mathrm{Al} 5$ & $0.6269(7)$ & $0.1202(7)$ & $-0.0036(10)$ & $0.005(5)$ \\
$\mathrm{Al} 6$ & $0.1238(6)$ & $0.6282(7)$ & $0.9519(8)$ & $0.007(6)$ \\
$\mathrm{Al} 7$ & $0.3708(6)$ & $0.6293(7)$ & $0.9760(13)$ & $0.012(3)$ \\
$\mathrm{Al} 8$ & $0.1233(7)$ & $0.8793(7)$ & $0.9787(13)$ & $-0.001(3)$ \\
O5 & $0.3983(10)$ & $0.2439(6)$ & $0.4338(11)$ & $0.027(6)$ \\
O6 & $0.5628(6)$ & $0.4028(5)$ & $0.1320(13)$ & $0.013(5)$ \\
O7 & $0.5457(8)$ & $0.1035(5)$ & $0.1446(11)$ & $0.032(5)$ \\
O8 & $0.7546(5)$ & $0.5910(9)$ & $0.5102(9)$ & $-0.004(3)$ \\
O9 & $0.5957(5)$ & $0.4375(6)$ & $0.8201(13)$ & $0.011(5)$ \\
O10 & $0.8984(5)$ & $0.4459(7)$ & $0.7976(8)$ & $0.08(3)$ \\
O11 & $0.7539(6)$ & $0.9027(10)$ & $0.5520(10)$ & $0.018(4)$ \\
O12 & $0.8916(5)$ & $0.0345(7)$ & $0.8323(14)$ & $0.013(4)$ \\
O13 & $0.6069(5)$ & $0.0378(8)$ & $0.8490(11)$ & $0.024(5)$ \\
O14 & $0.1050(11)$ & $0.2433(6)$ & $0.4026(11)$ & $0.027(6)$ \\
\hline & $0.9646(7)$ & $0.1066(5)$ & $0.1224(14)$ & $0.014(4)$ \\
O16 & $0.9571(7)$ & $0.3947(5)$ & $0.0996(8)$ & $-0.001(3)$ \\
\hline & & & &
\end{tabular}


Table S3. Interatomic distances $(\AA)$ and angles $\left({ }^{\circ}\right)$ for stoichiometric yeelimite at room temperature.

\begin{tabular}{|c|c|c|c|}
\hline \multicolumn{2}{|c|}{$\mathrm{Ca}(1) \mathrm{O} 6$} & \multicolumn{2}{|c|}{$\mathrm{Ca}(2) \mathrm{O} 6$} \\
\hline $\mathrm{Ca}(1)-\mathrm{O}(2)$ & $2.334(20)$ & $\mathrm{Ca}(2)-\mathrm{O}(2)$ & $2.687(22)$ \\
\hline $\mathrm{Ca}(1)-\mathrm{O}(10)$ & $2.916(20)$ & $\mathrm{Ca}(2)-\mathrm{O}(4)$ & $2.530(23)$ \\
\hline $\mathrm{Ca}(1)-\mathrm{O}(14)$ & $2.334(18)$ & $\mathrm{Ca}(2)-\mathrm{O}(7)$ & $2.999(21)$ \\
\hline $\mathrm{Ca}(1)-\mathrm{O}(14)$ & $3.187(18)$ & $\mathrm{Ca}(2)-\mathrm{O}(11)$ & $2.284(19)$ \\
\hline $\mathrm{Ca}(1)-\mathrm{O}(15)$ & $2.279(19)$ & $\mathrm{Ca}(2)-\mathrm{O}(12)$ & $2.286(19)$ \\
\hline $\mathrm{Ca}(1)-\mathrm{O}(16)$ & 2.396(18) & $\mathrm{Ca}(2)-\mathrm{O}(13)$ & $2.250(19)$ \\
\hline \multicolumn{2}{|c|}{$\mathrm{Ca}(3) \mathrm{O} 6$} & \multicolumn{2}{|c|}{$\mathrm{Ca}(4) \mathrm{O} 6$} \\
\hline $\mathrm{Ca}(3)-\mathrm{O}(3)$ & $2.054(20)$ & $\mathrm{Ca}(4)-\mathrm{O}(1)$ & $2.432(16)$ \\
\hline $\mathrm{Ca}(3)-\mathrm{O}(6)$ & $2.704(22)$ & $\mathrm{Ca}(4)-\mathrm{O}(4)$ & $2.532(15)$ \\
\hline $\mathrm{Ca}(3)-\mathrm{O}(8)$ & 2.339(17) & $\mathrm{Ca}(4)-\mathrm{O}(5)$ & $2.310(16)$ \\
\hline $\mathrm{Ca}(3)-\mathrm{O}(8)$ & $2.870(18)$ & $\mathrm{Ca}(4)-\mathrm{O}(6)$ & $2.289(18)$ \\
\hline $\mathrm{Ca}(3)-\mathrm{O}(9)$ & $2.337(21)$ & $\mathrm{Ca}(4)-\mathrm{O}(7)$ & $2.208(18)$ \\
\hline $\mathrm{Ca}(3)-\mathrm{O}(10)$ & $2.370(21)$ & $\mathrm{Ca}(4)-\mathrm{O}(9)$ & 2.792(18) \\
\hline \multicolumn{2}{|c|}{$\mathrm{Al}(1) \mathrm{O} 4$} & \multicolumn{2}{|c|}{$\mathrm{Al}(2) \mathrm{O} 4$} \\
\hline $\mathrm{Al}(1)-\mathrm{O}(6) \mathrm{x} 2$ & $1.729(4)$ & $\mathrm{Al}(2)-\mathrm{O}(7) \times 2$ & $1.747(4)$ \\
\hline $\mathrm{Al}(1)-\mathrm{O}(9) \mathrm{x} 2$ & $1.730(4)$ & $\mathrm{Al}(2)-\mathrm{O}(13) \mathrm{x} 2$ & $1.751(4)$ \\
\hline $\mathrm{O}(6)-\mathrm{Al}(1)-\mathrm{O}(6)$ & 121.5(8) & $\mathrm{O}(7)-\mathrm{Al}(2)-\mathrm{O}(7)$ & $115.2(7)$ \\
\hline $\mathrm{O}(6)-\mathrm{Al}(1)-\mathrm{O}(9)$ & 104.2(4) & $\mathrm{O}(7)-\mathrm{Al}(2)-\mathrm{O}(13)$ & $110.0(4)$ \\
\hline $\mathrm{O}(6)-\mathrm{Al}(1)-\mathrm{O}(9)$ & $104.6(5)$ & $\mathrm{O}(7)-\mathrm{Al}(2)-\mathrm{O}(13)$ & 103.4(4) \\
\hline $\mathrm{O}(6)-\mathrm{Al}(1)-\mathrm{O}(9)$ & 104.6(5) & $\mathrm{O}(7)-\mathrm{Al}(2)-\mathrm{O}(13)$ & 103.4(4) \\
\hline $\mathrm{O}(6)-\mathrm{Al}(1)-\mathrm{O}(9)$ & 104.2(4) & $\mathrm{O}(7)-\mathrm{Al}(2)-\mathrm{O}(13)$ & $110.0(4)$ \\
\hline $\mathrm{O}(9)-\mathrm{Al}(1)-\mathrm{O}(9)$ & 118.9(8) & $\mathrm{O}(13)-\mathrm{Al}(2)-\mathrm{O}(13)$ & $115.2(7)$ \\
\hline \multicolumn{2}{|c|}{$\mathrm{Al}(3) \mathrm{O} 4$} & \multicolumn{2}{|c|}{$\mathrm{Al}(4) \mathrm{O} 4$} \\
\hline $\mathrm{Al}(3)-\mathrm{O}(12) \times 2$ & $1.759(4)$ & $\mathrm{Al}(4)-\mathrm{O}(10) \times 2$ & $1.742(4)$ \\
\hline $\mathrm{Al}(3)-\mathrm{O}(15) \times 2$ & $1.761(4)$ & $\mathrm{Al}(4)-\mathrm{O}(16) \times 2$ & $1.750(4)$ \\
\hline $\mathrm{O}(12)-\mathrm{Al}(3)-\mathrm{O}(12)$ & $114.9(7)$ & $\mathrm{O}(10)-\mathrm{Al}(4)-\mathrm{O}(10)$ & $119.0(7)$ \\
\hline $\mathrm{O}(12)-\mathrm{Al}(3)-\mathrm{O}(15)$ & $107.9(4)$ & $\mathrm{O}(10)-\mathrm{Al}(4)-\mathrm{O}(16)$ & 101.3(4) \\
\hline $\mathrm{O}(12)-\mathrm{Al}(3)-\mathrm{O}(15)$ & $106.9(4)$ & $\mathrm{O}(10)-\mathrm{Al}(4)-\mathrm{O}(16)$ & $110.2(4)$ \\
\hline $\mathrm{O}(12)-\mathrm{Al}(3)-\mathrm{O}(15)$ & $106.9(4)$ & $\mathrm{O}(10)-\mathrm{Al}(4)-\mathrm{O}(16)$ & $110.2(4)$ \\
\hline $\mathrm{O}(12)-\mathrm{Al}(3)-\mathrm{O}(15)$ & $107.9(4)$ & $\mathrm{O}(10)-\mathrm{Al}(4)-\mathrm{O}(16)$ & 101.3(4) \\
\hline $\mathrm{O}(15)-\mathrm{Al}(3)-\mathrm{O}(15)$ & $112.5(7)$ & $\mathrm{O}(16)-\mathrm{Al}(4)-\mathrm{O}(16)$ & $115.7(7)$ \\
\hline \multicolumn{2}{|c|}{$\mathrm{Al}(5) \mathrm{O} 4$} & \multicolumn{2}{|c|}{$\mathrm{Al}(6) \mathrm{O} 4$} \\
\hline $\mathrm{Al}(5)-\mathrm{O}(5)$ & $1.743(6)$ & $\mathrm{Al}(6)-\mathrm{O}(8)$ & $1.741(6)$ \\
\hline $\mathrm{Al}(5)-\mathrm{O}(7)$ & $1.735(6)$ & $\mathrm{Al}(6)-\mathrm{O}(10)$ & $1.737(6)$ \\
\hline $\mathrm{Al}(5)-\mathrm{O}(11)$ & $1.758(6)$ & $\mathrm{Al}(6)-\mathrm{O}(14)$ & $1.753(6)$ \\
\hline $\mathrm{Al}(5)-\mathrm{O}(13)$ & $1.746(6)$ & $\mathrm{Al}(6)-\mathrm{O}(16)$ & $1.742(6)$ \\
\hline $\mathrm{O}(7)-\mathrm{Al}(5)-\mathrm{O}(7)$ & 105.0(6) & $\mathrm{O}(8)-\mathrm{Al}(6)-\mathrm{O}(10)$ & $104.3(5)$ \\
\hline $\mathrm{O}(7)-\mathrm{Al}(5)-\mathrm{O}(13)$ & $115.4(7)$ & $\mathrm{O}(8)-\mathrm{Al}(6)-\mathrm{O}(14)$ & $118.2(7)$ \\
\hline $\mathrm{O}(7)-\mathrm{Al}(5)-\mathrm{O}(13)$ & 106.6(6) & $\mathrm{O}(8)-\mathrm{Al}(6)-\mathrm{O}(16)$ & $105.4(5)$ \\
\hline $\mathrm{O}(7)-\mathrm{Al}(5)-\mathrm{O}(13)$ & 109.0(6) & $\mathrm{O}(10)-\mathrm{Al}(6)-\mathrm{O}(14)$ & 107.3(5) \\
\hline $\mathrm{O}(7)-\mathrm{Al}(5)-\mathrm{O}(13)$ & $116.0(6)$ & $\mathrm{O}(10)-\mathrm{Al}(6)-\mathrm{O}(16)$ & $115.9(6)$ \\
\hline $\mathrm{O}(13)-\mathrm{Al}(5)-\mathrm{O}(13)$ & 105.1(6) & $\mathrm{O}(14)-\mathrm{Al}(6)-\mathrm{O}(16)$ & 106.3(6) \\
\hline \multicolumn{2}{|c|}{$\mathrm{Al}(7) \mathrm{O} 4$} & \multicolumn{2}{|c|}{$\mathrm{Al}(8) \mathrm{O} 4$} \\
\hline $\mathrm{Al}(7)-\mathrm{O}(5)$ & $1.735(6)$ & $\mathrm{Al}(8)-\mathrm{O}(11)$ & 1.763(6) \\
\hline $\mathrm{Al}(7)-\mathrm{O}(6)$ & $1.724(6)$ & $\mathrm{Al}(8)-\mathrm{O}(12)$ & $1.761(6)$ \\
\hline $\mathrm{Al}(7)-\mathrm{O}(8)$ & $1.737(6)$ & $\mathrm{Al}(8)-\mathrm{O}(14)$ & $1.760(6)$ \\
\hline
\end{tabular}




\begin{tabular}{|c|c|c|c|}
\hline $\mathrm{Al}(7)-\mathrm{O}(9)$ & $1.730(6)$ & $\mathrm{Al}(8)-\mathrm{O}(15)$ & $1.756(6)$ \\
\hline $\mathrm{O}(5)-\mathrm{Al}(7)-\mathrm{O}(6)$ & $108.2(6)$ & $\mathrm{O}(11)-\mathrm{Al}(8)-\mathrm{O}(12)$ & $106.3(6)$ \\
\hline O(5)-Al(7)-O(8) & $120.6(6)$ & $\mathrm{O}(11)-\mathrm{Al}(8)-\mathrm{O}(14)$ & $115.5(6)$ \\
\hline $\mathrm{O}(5)-\mathrm{Al}(7)-\mathrm{O}(9)$ & 104.1(6) & $\mathrm{O}(11)-\mathrm{Al}(8)-\mathrm{O}(15)$ & $106.8(6)$ \\
\hline $\mathrm{O}(6)-\mathrm{Al}(7)-\mathrm{O}(8)$ & 104.6(6) & $\mathrm{O}(12)-\mathrm{Al}(8)-\mathrm{O}(14)$ & 105.2(6) \\
\hline $\mathrm{O}(6)-\mathrm{Al}(7)-\mathrm{O}(9)$ & $115.9(5)$ & $\mathrm{O}(12)-\mathrm{Al}(8)-\mathrm{O}(15)$ & $115.7(5)$ \\
\hline $\mathrm{O}(8)-\mathrm{Al}(7)-\mathrm{O}(9)$ & 104.0(6) & $\mathrm{O}(14)-\mathrm{Al}(8)-\mathrm{O}(15)$ & $107.7(6)$ \\
\hline \multicolumn{2}{|c|}{$\mathrm{S}(1) \mathrm{O} 4$} & & \\
\hline $\mathrm{S}(1)-\mathrm{O}(1)$ & $1.4987(33)$ & & \\
\hline $\mathrm{S}(1)-\mathrm{O}(2)$ & $1.5027(32)$ & & \\
\hline $\mathrm{S}(1)-\mathrm{O}(3)$ & $1.5004(33)$ & & \\
\hline$S(1)-O(4)$ & $1.5016(33)$ & & \\
\hline $\mathrm{O}(1)-\mathrm{S}(1)-\mathrm{O}(2)$ & $110.0(5)$ & & \\
\hline $\mathrm{O}(1)-\mathrm{S}(1)-\mathrm{O}(3)$ & 110.1(5) & & \\
\hline $\mathrm{O}(1)-\mathrm{S}(1)-\mathrm{O}(4)$ & 109.3(5) & & \\
\hline $\mathrm{O}(2)-\mathrm{S}(1)-\mathrm{O}(3)$ & 109.5(5) & & \\
\hline $\mathrm{O}(2)-\mathrm{S}(1)-\mathrm{O}(4)$ & 108.2(4) & & \\
\hline $\mathrm{O}(3)-\mathrm{S}(1)-\mathrm{O}(4)$ & 109.7(5) & & \\
\hline
\end{tabular}


Table S4. Rietveld quantitative phase analysis results for a commercial CSA cement using both the bibliographic and refined orthorhombic structure for yeelimite (reporting final Rietveld figures of merit). ICSD collection codes are also included.

\begin{tabular}{c|ccc} 
Phase & $\mathrm{wt} \%$ & $\mathrm{wt} \%$ & $\mathrm{ICSD}$ \\
\hline yeelimite (previously-reported & $48.7(2)$ & - & 80361 \\
structure) & - & $47.7(1)$ & - \\
yeelimite (structure - this study) & $31.0(2)$ & $30.9(1)$ & 151692 \\
Gypsum & $10.4(3)$ & $11.1(3)$ & 81096 \\
$\beta$-belite & $6.5(2)$ & $6.7(2)$ & 62149 \\
$\mathrm{CaTiO}_{3}$ & $1.5(1)$ & $1.4(1)$ & 9863 \\
$\mathrm{MgO}$ & $1.2(1)$ & $1.4(1)$ & 67691 \\
Akermanite & $0.7(1)$ & $0.8(1)$ & 9197 \\
\hline Tetracalcium aluminoferrate & 8.7 & 7.6 & - \\
$\mathrm{R}_{\mathrm{WP}}-\%$ & 6.9 & 4.8 & - \\
\hline $\mathrm{R}_{\mathrm{F}}$ (yeelimite) - \% & &
\end{tabular}

Figure S1. Rietveld plot for the commercial CSA cement using the orthorhombic crystal structure for yeelimite $\left(C_{4} A_{3} \underline{S}\right.$ in cement notation), with peaks for a given phase labeled. $\beta-C_{2} S$ stands for belite in cement notation.

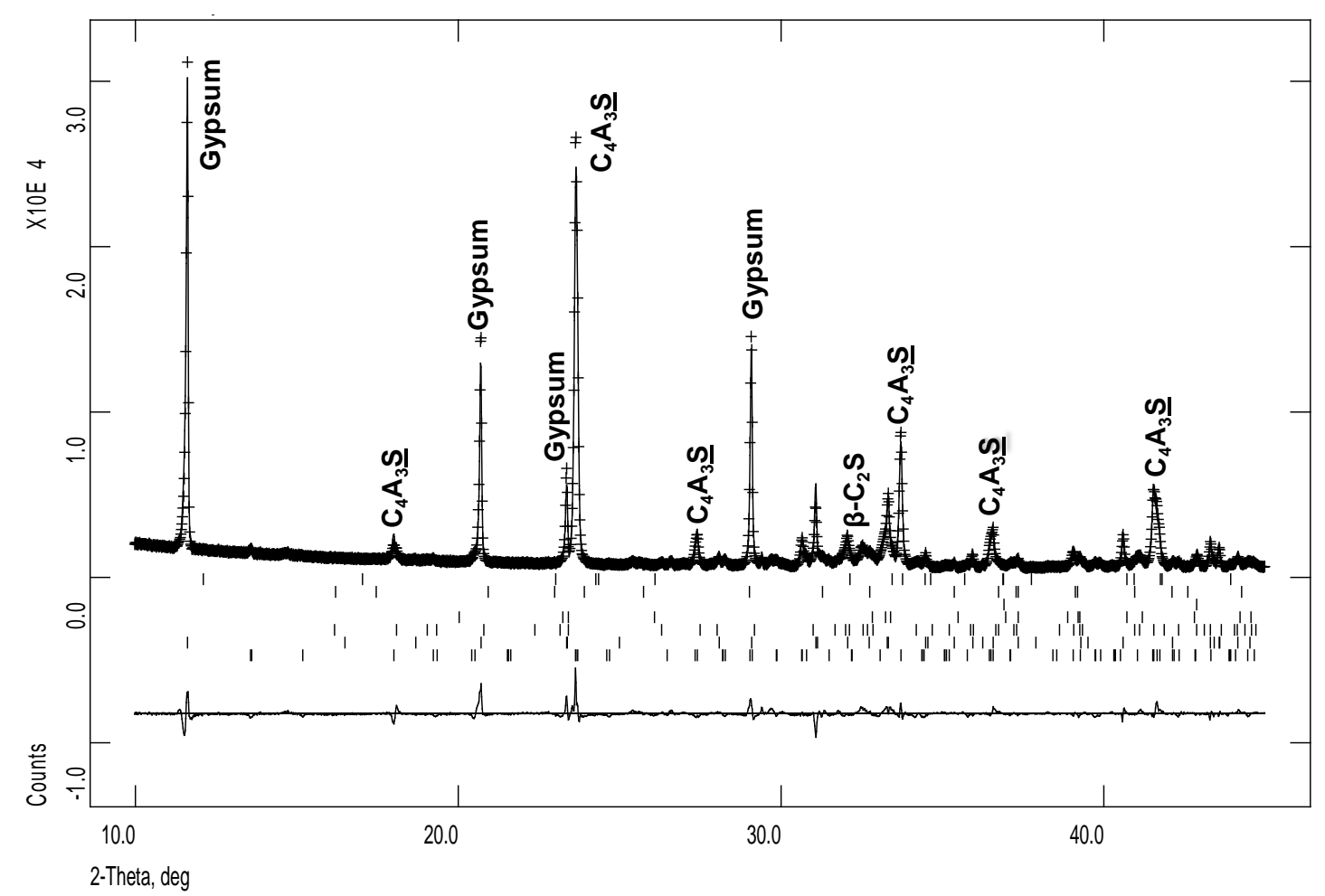


Figure S2. Rietveld plot for stoichiometric yeelimite at $800{ }^{\circ} \mathrm{C}$. The average structure has been modeled in the cubic $I \underline{4} 3 \mathrm{~m}$ space group. Inset shows a detail in the high-angle region.

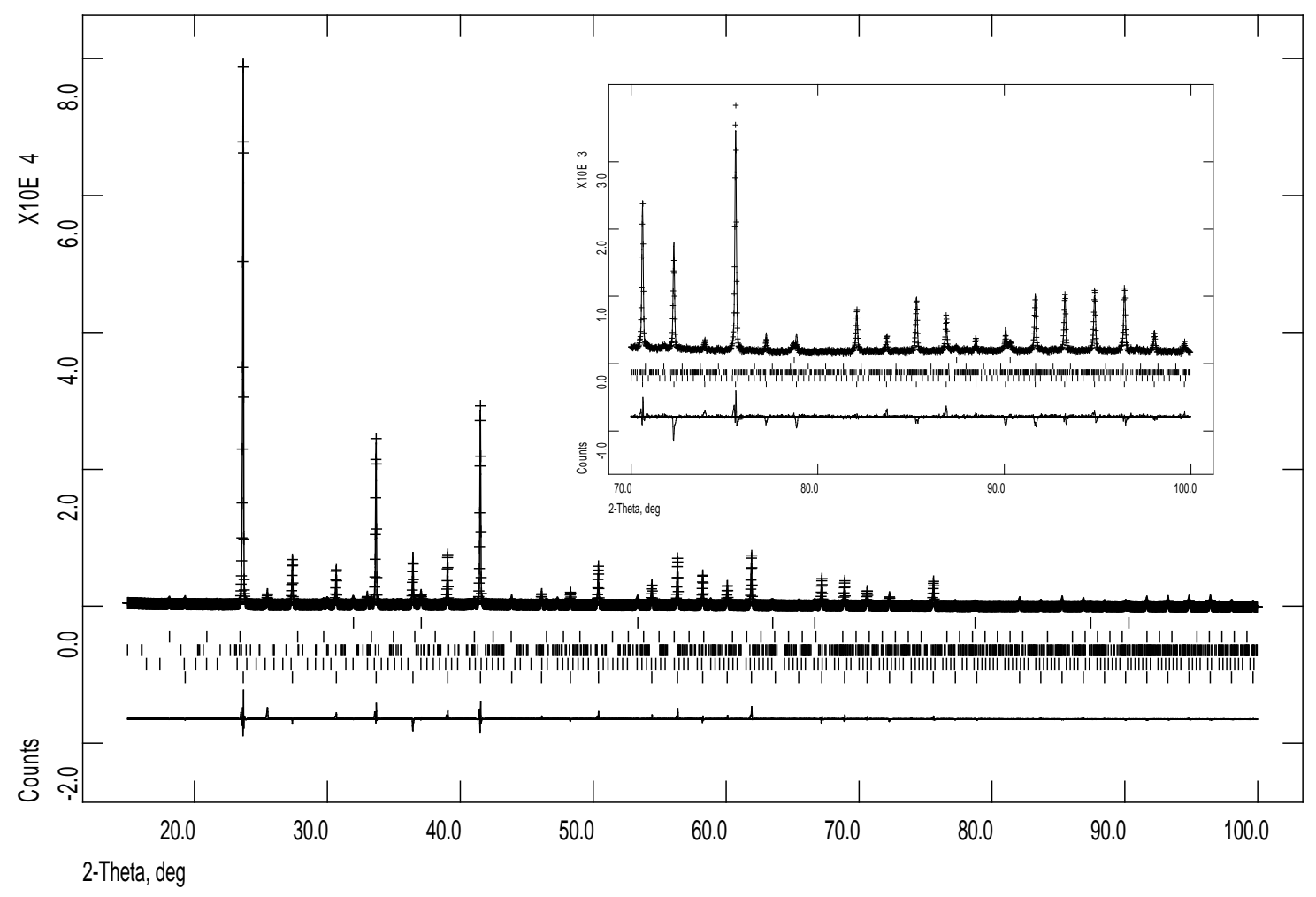

